\title{
PEACE, WAR AND AN ARMED CONFLICT AS AN OBJECT OF THE RESEARCH OF POLEMOLOGY
}

\begin{abstract}
War, society and country change systematically. Therefore, war is and will be an object of the research. In all probability the process of war changes shall be assumed as evolutionary. Consequently, the research should be acknowledged as significant since they allow to comprehend the nature of these occurrences in more transparent way.

Polemological approach to the research of war has a negative nature and is used to eliminate war from the entire social life. It is notable that war used to be perceived usually as a mean to establish peace, not as an end in itself. The difference of polemological approach is about changing the war status. War is not a practical mean to establish peace but the object of cognition. The aim of the cognition is to eliminate war definitively from theory and practice of human relationships. Therefore, war is not a tool but the object of scientific inquiry. In cognitive conception the polemological research of war is the source of knowledge about war etiology, anatomy and social functions. In utilitarian conception it allows to reach conclusions how to act in order to avoid war. Knowledge acquired in such way indicates how to create reality so that war would become a historical category. The result of scientific cognition is knowledge which should be used to prevent war. The sense of polemological approach towards research of war should be perceived in cognitive and practical aspect. The cognitive element is mostly about explaining the cause and effect relationships, formulating and verifying hypothesis and statements. The practical aspect is about didactic and informative assignments. Above all, it refers to the effect on society and decision makers.
\end{abstract}

Keywords: peace, polemology, war, armed conflict.

\section{INTRODUCTION}

After the end of the Cold War, the cultural, ethnical as well as national divisions were supposed to be displaced by a community of value (liberty, democracy) and economic interests. However, when hopeful expectations were arising, there occurred signs of global differences, traditions and habits deep-rooted in the culture, civilization, religion as well as identity, which resisted and opposed to the common admittance of western civilization (democratic liberalism and market capitalism) ${ }^{2}$. Fundamental assumptions, formulated together with the end of the Cold War, fell as quick as they were expressed in the following famous sentence of Francis Fukuyama taken from the book entitled

\footnotetext{
${ }^{1}$ Waldemar Krzton PhD, Department of Humanities, Faculty of Humanities, Rzeszow University of Technology, ul. Powstancow Warszawy 8, 35-959 Rzeszow, tel. 177432337, e-mail:

wkrzton@prz.edu.pl

${ }^{2}$ R. Kagan, Powrót historii i koniec marzeń, Dom Wydawniczy REBIS, Poznań 2009, pp. 14-15.
} 
"The End Of History And The Last Man": "At the end of history the liberal democracy is left in the battlefield without any serious ideological competitor"3.

The XXI century, as the age of information, is the time of the greatest advancement in the history of mankind but, at the same time, it is the century abundant in conflicts of different sort, including armed conflicts. Such phenomenon is likely to be still wellknown in social life in the nearest future as well.

The previous theories of conducting wars were changing together with subsequent social and systemic transformations as well as with the development of science and technology. The character of war conflicts was determined by development of the means of war to a large extent. The nature of an armed fight was undergoing systematic revaluations. The statement concerning the possibility of the complete removal of the phenomenon called war from the social life seems to be pure utopia. Aims, character and ways of conducting the future armed conflicts are undoubtedly changing, we are currently experiencing this after all. However, the war as a social phenomenon is probably going to have the long-lived future.

The number of wars and armed conflicts in the world has not decreased. Their nature, on the other hand, has evidently changed. The transformation of the nature of wars and armed conflicts as well as failures of the countries of Western civilization participating in them, cause the necessity to undertake research on war in general, particularly on the contemporary war.

Inquiries into the genesis, the essence and the character of wars as well as into the nature of peace and ways of its making are not the phenomenon of the modern world. Their history is very long because it dates back into an ancient oriental idea. The research on war and peace include two methodological and theoretical orientations ${ }^{4}$ : (1) peace research orientation, also known as irenological orientation (from Greek eirene - peace); (2) polemological orientation (from Greek polemos - war, combat, fight).

It should be emphasized most generally that, without presenting here any particular differences dividing the orientations, the representatives of the former claim that the way to know the essence and source of wars leads through the acquaintance with conditions, nature and structure of peace, whereas the representatives of the latter are of the opinion that it is necessary to act quite the contrary, to research the sources of wars first, their essence and character, and only then to determine the conditions of their elimination from the social life. It seems that polemology is methodologically more justified because, according to its assumption, in order to build peace it is necessary to simultaneously limit, decrease and eventually abolish the sources of the armed conflicts and wars. All this evidences that, regardless of the numerous methodological and theoretical directions of research on war and peace, polemology is rising in strength and meaning more and more. It manifests in various forms of actions leading to creating an interdisciplinary science on war and peace.

${ }^{3}$ F. Fukuyama, Koniec historii, Zysk i S-ka, Poznań 1996, p. 211.

${ }^{4}$ J. Borgosz, Drogi i bezdroża filozofii pokoju (od Homera do Jana Pawta II), Warszawa 1989, p. 226-227. 


\section{PEACE AND WAR AS SUBJECTS OF RESEARCH}

The oldest definition of peace functioning in the ancient Rome was the ascertainment that peace (pax) meant the absence of war (absentia belli). The most popular meaning of the concept is as above. According to the Dictionary of Polish Language, peace is "a relation between countries which do not conduct war between themselves" . The above definition was supplemented by the following term: "An agreement on the termination of war acts between countries conducting war". This latter understanding constitutes a very narrow and practical meaning of the term peace. Some scientists assume that war is not the antithesis of peace. They treat peace as a part of war, as its termination and declaration of reconciliation ${ }^{6}$.

Professor Świniarski enumerates five major trends of acquainting and perceiving peace:

1) polemological - aiming at disarmament with the vision of peace, initiated by Gaston Bouthol - the unarmed peace.

2) functionalist - preferring international institutions implementing peace as their task, aim and functions - controlled peace.

3) sociological and cultural (historical) - preferring peace by equality of forces the armed peace.

4) sociological and critical - suggesting cooperation on the entire planes and levels of interpersonal relations, the lack of personal and structural violence the positive peace.

5) philosophical and theoretical - personal and structural security are its research perspective ${ }^{7}$.

According to Bolesław Balcerowicz, the explanations of peace suggested by various research centres are not in conflict with one another, on the contrary, they perfectly permeate and supplement one another. Professor Balcerowicz indicates at four major research approaches: politological, sociological, psychological, and ethical ${ }^{8}$.

War is one of the oldest terms. In the past, each resolution of a dispute by means of arms was called war. Throughout history, the comprehension of war had been changing together with the development of societies, civilisations and technology. War was always a subject of particular interest of rulers, strategists, historians, writers, and thinkers. A Chinese thinker Sun Tzu claimed that "The art of war is of vital importance to the State. It is a matter of life and death, a road either to safety or to ruin. Hence it is a subject of inquiry which can on no account be neglected". ${ }^{9}$ On the other hand, Arnold Toynbee, in his book "War and Civilisation", wrote the following: "by reaching out for a sword,

\footnotetext{
${ }^{5}$ Stownik języka polskiego, t. 2, PWN, Warszawa 1979, p. 773. Numerous authors wrote about the war-peace alternative, it is not possible to enumerate them all. This interpretation is also popular with social studies.

${ }^{6}$ H. A. Jacobsen, Imperatyw pokoju. Polityka i wojna w XX wieku, Poznań 2000, p. 39.

${ }^{7}$ J. Świniarski, Myśl filozoficzna w polemologii, [in:] Huzarski M., Szulc B. (ed.), Metodologiczna tożsamość polemologii, AON, Warszawa 2010, p. 75.

${ }^{8}$ B. Balcerowicz, O pokoju. O wojnie, Wydawnictwo Rambler, Warszawa 2013, pp. 18-19.

${ }^{9}$ Sun Tzu, Sztuka wojny, Wydawnictwo HELION, Gliwice 2008, p. 64. Tao is „road” in Chinese.
} 
a man usually expects that he is able to use it so effectively that it will have nothing to do in the future. However, such hope is an illusion". ${ }^{10}$

According to Bolesław Balcerowicz, the major research problems of wars has become their:

1) Etiology - thoroughly covering research of the causes of wars, armed conflicts;

2) Anatomy - war-inside-analysis-oriented, of its structure and infrastructure, its elements, in mutual connections and relations;

3) Functions - in individual civilisations, concentrating on the present day at the same time ${ }^{11}$.

Gaston Bouthoul, the creator of polemology, differentiated the following functions of wars:

1) Existential (tribal and ancestral civilisations);

2) Economic (in higher stages of social development: extending territories, conquering new wealth, labour, strategic positions);

3) Demographic (regulation of population growth);

4) Ethic (counteracting moral depravity of societies);

5) Psychological (penetrating patriotic awareness and national pride);

6) Defending a specific religion or expanding a religious doctrine on other territories ${ }^{12}$.

The research on war has been undertaken in four crucial circles. The first circle is created by a group of sociologists regarding the war analyses as a social phenomenon. The second, a group of political scientists, includes the scientists treating war as a continuation of politics. The third circle is represented by ethical philosophers. The fourth was established by representatives of old military sciences, currently formed by representatives of defensibility and security sciences. A particular place is occupied by the fourth circle because it is the environment in which theories of wars were shaped, the research of history of wars and army as well as the war art was performed.

\section{WAR AND AN ARMED CONFLICT - A POLOMOLOGICAL APPROACH}

The term "polemology" has been in force since 1945 but it has not been known to a broader recipient group. Therefore, it is the cause of asking the following question: what is polemology? Professor Ciborowski answers that question: "[...] polemology is an area of knowledge covering the identification of cause-and-effect relations concentrated around wars and armed conflicts. However, its message is the demonstration of war tragedies and contributing to shaping peace in this way". ${ }^{13}$

The theory and term ,polemology” was created by Gaston Bouthoul, a French scientist, who in 1937 put forward an idea to appoint an interdisciplinary peace science, undertaking to investigate the causes of wars, analyse their structure and role. This branch of science was supposed to aim for a scientific study of dependent and independent

\footnotetext{
${ }^{10}$ A. Toynbee, Wojna i cywilizacja, Warszawa 1963, p. 152.

${ }^{11}$ B. Balcerowicz, O pokoju ... op. cit., p. 27.

${ }^{12}$ K. Drabik, Polemologia dla pokoju, part I, Zeszyty Naukowe AON nr 3 (76), AON, Warszawa 2009, p. 346.

${ }^{13}$ L. Ciborowski, Polemologia - stan obecny i perspektywy [w:] Huzarski M., Szulc B. (ed.), Metodologiczna tożsamość polemologii, AON, Warszawa 2010, p. 10.
} 
premises of permanent peace to the national as well as international extent. The Second World War precipitated the realization of the idea. In 1945, Bouthol founded in Paris ascientific and research institution under the name Institut Français de Polémologie. While searching for a proper name for the science, he wanted it to be different from the terminology to date within the scope, but also to formulate in a true manner above all its subject and individual features towards the following war sciences: strategy and tactics. Bouthol named the science „Polemology”.

The etymology of the term „Polemology” is described by its subject matter. According to the Greek source of Polemology, its cognition subject is ,war, dispute, conflict, fight, laws governing the war and fight in various actual situations. Polemology is a science about wars and it aims at discovering their causes so as to eliminate wars from the

life

of the people". ${ }^{14}$ The following thesis is a research motive for polemologists: From the cognition of war to the cognition of peace, or otherwise: Si tu veux la paix connais la guerre, which can be translated as: 'if you want peace, know war'. The statement is different from the Roman saying (Pax Romana $)^{15}$ - Si vis pacem parabellum, which means: 'if you want peace, prepare for war'. It led to such situation that peace was maintained by the arms race which was limited by war. Here, a crucial difference in the guidelines aiming at maintaining peace can be noticed. In the preparations for war, any alarming, confrontational as well as aggressive undertakings should be noted. On the other hand, becoming acquainted with sources or causes of wars and armed conflicts can commence actions in favour of peace.

Polemologists assume the research of the phenomenon of war and armed conflicts in an interdisciplinary manner and not only within the military scope (the war art). Within the polemological meaning, discovering war serves different purposes than the war art being the science analysing war so as to lead it efficiently. By discovering the nature of wars, military sciences (defensibility sciences) were aimed at (aim at) achieving victory over a potential opponent, so as to ensure sovereignty to its own country. Such opposite of aims describes polemology as rather peace knowledge, whereas the wart art is considered to be rather military. The following sayings can reflect the above: on the one hand, if you want peace, know war (in order to eliminate it), on the other hand, if you want peace, prepare for war (in order to win it). Knowledge of war and its sources as well as its causes can be used to eliminate the phenomenon and to initiate it at the same time. Therefore, war as a subject matter of discovery, has been within the sphere of interest of polemology as well as the war art.

The bilateral cognitive interest of polemology and the war art seems to be proper because polemology searches for manners to limit war, and the contemporary war art looks for the ways to alleviate its consequences. It follows that contemporary scopes of interest of both sciences combine in numerous spheres (limitation of killing and the extent of wars). The research area of defensibility sciences changes from a violence domain, destroying the armed forces of the enemy, seizing its territory

\footnotetext{
${ }^{14}$ J. Świniarski, Myśl filozoficzna ... op. cit., p. 64.

${ }^{15} \mathrm{~W}$. Kopaliński, Stownik wyrazów obcych $i$ zwrotów obcojęzycznych, wydanie XVIII, PW „Wiedza Powszechna”, Warszawa 1989, p. 386. Pax Romana (Latin), Roman peace: the peace which is imposed (by the Roman Empire, for instance) to a conquered nation and maintained by means of the armed forces.
} 
and forcing it to fulfil our will (Clausewitz), into actions intending to make war more acceptable for a society: (1) it should not involve ordinary citizens, so it should be conducted by a professional army; (2) it should be short or even swift; (3) it should be clean, surgical, with damages, even of the enemy, maintained within reasonable limits. ${ }^{16}$

It should be remarked here that peace, war and conflicts are a subject of research in certain parts of related branches of science. All the sciences such as history, philosophy, sociology, the war art, gather theoretical knowledge on peace, war and conflicts achieved in the process of scientific research. Until the creation of polemology as a science, there was no discipline which would perform a synthesis of the knowledge and would use it in research. This is the essence of the interdisciplinary approach in the polemological research. The phenomenon of war as well as its preparation and conducting should be considered comprehensively and interpreted from different points of view. Almost each cognition process of contemporary phenomena of a social character, which is war, is interdisciplinary in its nature because phenomena are eclectic in themselves.

Polemology is the idea of building an interdisciplinary science dealing with phenomena of war and peace. Polemologists emphasized, and still emphasize, the interdisciplinary character of the research on causes, an analysis of their structure and the role of wars, without opposing to the detailed research: philosophical, sociological, and ethical research. They think that none of detailed sciences in the present world is able to analyse such versatile phenomena as wars and peace. The knowledge of the history of wars, the war art, the defensibility and security sciences, political science, economy, sociology and others will assist in understanding the phenomenon of war, crisis and peace.

Polemology as a science was an answer to realized consequences of the Second World War. Its tragic results made people aware of the fact that, in order to live in peace, it is necessary to become acquainted with the etiology of war. The outcome of the scientific cognition of polemology is the making of peace. Therefore, the result of the polemological research should first of all be used to counteract the causes of formation of conflicts. According to Andrzej Czupryński, there are no reservations as for the following points: (1) That from the ontological point of view, war is a subject matter of cognition but the subject of the research are its conditions in the entire spheres of a man's social life; (2) The epistemological aspect in polemology applies to cognition theory of war. This, in turns, demands the identification of correlation between numerous factors that condition it. Epistemology of polemology determines research methods suitable for learning the causes of war; (3) The axiological aspect of polemology relates to the estimation of a product of its scientific cognition ${ }^{17}$.

Having performed the analyses and comparisons of varied terminological manners, professor Huzarski suggests the following definition of polemology: "Polemology is a scientific specialization concentrating upon the research of wars and armed conflicts

${ }^{16}$ M. Castells, Spoteczeństwo sieci, Warszawa 2008, p. 454.

${ }^{17}$ A. Czupryński, Sztuka wojenna $i$ polemologia $w$ aspekcie wspólnego obiektu poznania naukowego, [w:] A. Czupryński, A. Polak, (red.), Od sztuki wojennej do polemiologii. The research given to professor Michał Huzarski on his seventieth birthday anniversary. AON, Warszawa 2012, p. 414. 
in an interdisciplinary manner. It analyses their nature and conditions, locates their periodicity, intensity, cause-and-effect relations as well as typology in time and space. Polemology analyses armed conflicts and wars of the past, present and future" 18 .

The major research problem of polemology can be formulated in the form of questions ${ }^{19}$ :

1) Why did people fight and why do they fight?

2) Why did they arm and why do they arm?

3) Why did they produce and do they produce such fighting measures which can destroy both themselves and the civilization?

The Bouthoul French Institute of Polemology differentiates eight stages in the research process of war and peace ${ }^{20}$ : (1) Description of material facts; (2) /pure/ description of psychological /interpersonal/ behaviour of parties in fight; (3) The first level of explaining material and psychological facts, views, doctrines relating to particular wars; (4) The second level of interpretation including opinions and doctrines on wars in general; (5) A selection and ordering of facts; (6) Hypotheses on the functions of wars; (7) Hypotheses concerning the periodicality of wars; (8) Typology of societies and wars.

Therefore, polemology analyses the essence of wars in the aspect of building and maintaining peace. After discovering wars in the polemological manner, the exploration and evaluation of the phenomenon follow so as to determine conditions of threats and further development. The result of the research should include relations between causes and consequences of war and conditions of peaceful functioning. The analysis of wars for the purposes of peace is the aim of a significant social value leading to shaping peace by becoming acquainted with causes of wars. From the social point of view, the knowledge on the war prevention as well as the shaped system of values form the basis for peaceful coexistence. Polemology, as a social science, is inseparably related to the life of societies and countries. The polemological approach in the analysis of armed conflicts allows to search for their causes in numerous spheres of social life. The assumption of polemology is observation of the phenomenon of war and crisis in a similar manner as in the case of the analysis of other social phenomena.

Polemology as a science is characterised by the scopes of cognitive interests described as multicriteria research of wars and armed conflicts: (1) of the past (comparative, statistical, structural and other analyses); (2) of the present (identifying the problem); (3) of the future (prognostication) ${ }^{21}$. It relates to determining the nature of wars and armed conflicts (a marvel of the phenomenon, causes of aggressive behaviour), factors causing their periodicality - called rhythms of belligerence, determining factors of their intensity, measurement and comparison of their duration, and effecting a typological division.

\footnotetext{
${ }^{18}$ M. Huzarski, Przedmiot badań, zakres polemologii, Lecture, Phd Studies, WZiD AON, Warszawa 2012.

${ }^{19}$ J. Borgosz, Drogi i bezdroża ..., op. cit., p. 225.

${ }^{20}$ Zob. G. Bouthoul, Traité de polémologie, sociologies des guerres, doctrines et opinions sur la guerre, morphologies, Paris 1970, s. 18-25; cyt. za: J. Borgosz, Drogi i bezdroża filozofii pokoju /od Homera do Jana Pawta II/, Warszawa 1989, pp. 230-231.

${ }^{21}$ M. Huzarski, Wojna i pokój przedmiotem badań polemologiczno-irenologicznych. Działalność naukowo-dydaktyczna zakładu polemologii, [w:] red. M. Huzarski, A. Czupryński, Wojna i pokój przedmiotem badań polemologiczno-irenologicznych, AON, Warszawa 2012, p. 10
} 
Gaston Bouthoul claimed that, in order to determine rhythms of wars, it is necessary to consider the beginning of a conflict, and not the end. He justifies it with a moment of termination of mobilization processes of a country and commencement of its destruction. The analyses of rhythms of belligerence in a society should have an independent character because each of them is appropriate for a particular type of civilization. Andrzej Gałganek states that rhythms of belligerence vary together with changes of conditions of life, technological development, character of social institutions etc $^{22}$. Among primitive nations, war was seasonal and would occur usually after the harvest. The rhythm of war extends in time together with formation of countries. The difference between a state of war and a state of peace is becoming clear. Wars are conducted more scarcely and become an issue for professionals. The violence and intensity potential is increasing whereas the frequency is decreasing.

According to Michał Huzarski, polemology meets the following scholarship criteria ${ }^{23}$ :

1) an outlined subject matter of analyses exists which includes wars and armed conflicts in the interdisciplinary manner;

2) There exist teaching and scientific and research units as well as specialists who deal with polemology;

3) There exists a collection of studies and other sources of irenological and polemological knowledge;

4) There are typical methods as well as language applied in polemological research.

Various branches of science can find in war a specific level of their own interest but only polemology strives for determining a source and causes of conflicts by a comprehensive approach. It is polemology which attempts to become acquainted with sources and causes, which is called an etiology ${ }^{24}$ of a conflict. Andrzej Czupryński states that "War as a social phenomenon in polemology must be analysed not only in the aspect of the occurrence of armed violence, but also its widely understood etiology as a complex of causes. No phenomenon has a single cause, all the more war, which is commenced in an aspect of political, economic, social, cultural and other conditions whose influence is less visible". ${ }^{25}$

Therefore, polemology analyses sources and causes of past and present conflicts, and the prognostication as for the source and cause of future conflicts can be the consequence of the cognition. Identification of actual sources and causes as well as indicating threats of an outbreak of a conflict in the foreseeable future should be the result of the research.

\section{ETIOLOGY OF WARS AND ARMED CONFLICTS - AN OUTLINE OF THE PROBLEM}

While analysing the etiology of wars, polemological barometers are used by polemology to determine sources and causes of the occurrence of wars.

\footnotetext{
${ }^{22}$ A. Gałganek, Polemologia - badania nad wojna i pokojem, Sprawy Międzynarodowe no. 6, Warszawa 1986, p. 103.

${ }^{23}$ M. Huzarski, Wojna i pokój ... op. cit. p. 17.

${ }^{24}$ Stownik języka polskiego, t. 1, PWN, Warszawa 1978, p. 558. Etiology is a group of reasons and a science on sources and cases of conflicts at the same time.

${ }^{25}$ A. Czupryński, Sztuka wojenna ..., op. cit., p. 412.
} 
The barometers are as follows: geographical factors, long-term factors, economic factors, national structure barometers, short-term barometers ${ }^{26}$. Tadeusz Kęsoń develops three areas of war outbreaks ${ }^{27}$ : (1) structural causes dependent upon a level of intellectual development, technology, economic, agricultural, and industrial development, demographic situation, historical and geographical conditions; (2) economic causes, especially political: alliances, coalitions, changes and behaviour of the public opinion under the influence of propaganda, indoctrination and ideology; (3) accidental (direct) causes, unexpected incidents, provocations etc.

Kenneth Waltz ${ }^{28}$, while analysing the phenomenon of war, suggests to consider it in groups corresponding to concepts in which he notices the causes of the occurrence of wars ${ }^{29}$ : (1) Waltz perceives the causes of wars in the nature of man as an individual. Taking such perspective into consideration, it is possible to reduce them to biological factors and instincts, aggression caused by frustration, violence - aggression as a habit, or perceive them as a result of individual decisions of leaders; (2) He notices causes in the nature of societies, countries or political systems. The basis of the theoretical perspective is an assumption that pursuit for wars is an attribute of wrong systems, economic pacts or collective opinions, whereas peaceful attitude is an attribute of good systems. Here, an approach towards war may be enumerated as an outcome of social knowledge, as a result of the existence of old conflicts and divisions, as a result of economic divisions; (3) He refers the causes of war to the character of a community made by societies, their formal equality and the lack of 'natural' principles regulating their mutual existence.

When analysing the sources and causes of wars, a great deal of scientists consider them on three levels: of an individual, of a country, and of an international system ${ }^{30}$. The above division is consistent with opinions of philosophers, thinkers and army officers who dealt with problems of wars throughout history. It is extremely difficult to find what possesses a decisive influence on the outbreak of war: whether it is an individaual, a country or perhaps a structure of an international system. Researchers indicate that the sources of wars should be considered comprehensively, without limiting to one of them only.

The first level searches through the sources of wars within a man - in weaknesses of the human nature, the behaviour of every human and in his individual features. War is a human action. That is why, it needs to be born in human minds first in order to exist ${ }^{31}$. Therefore, while analysing the sources of wars, it is necessary to mention human motives

${ }^{26}$ T. Kęsoń, Pojęcie konfliktu $i$ wojny $w$ literaturze. Podejście polemologiczne $w$ badaniach konfliktów zbrojnych, Warszawa 2008, p. 14.

${ }^{27}$ Ibidem, p. 12.

${ }^{28}$ Kenneth Waltz (1924-) an American political scientist, a lecturer at Unversity of California and Columbia University. He is one of the most distinguished scientists in the field of international relations.

${ }^{29}$ K. Waltz, Man, the State and War a Theoretical Analysis, New York 1959; cyt. za: P. Chmielarz, Wojna a państwo. Wczoraj i dziś, Wydawnictwo Naukowe Scholar, Warszawa 2010, p. 16.

${ }^{30}$ The division applied by: K. Waltz, Man, the State and War a Theoretical Analysis, New York 1959, J. Nye, Konflikty międzynarodowe. Wprowadzenie do historii i teorii, Warszawa 2009; Ł. Smalec, Dwie wojny z Irakiem. Źródta, przyczyny, przebieg, przygotowanie, skutki, Warszawa 2012.

${ }^{31}$ M. Fryc, Wojna. Wspótczesne oblicze, Torun 2009, p. 47. 
which have always controlled people throughout history and induced them to various deeds, including war. The motives are: egoism, thoughtlessness, weakness, aggressive tendencies, and striving for domination. The research of individual and group behaviour of the man head for different directions. However, they have one common denominator, which is a question whether the man applies violence because it is his nature or the capability of applying violence is revealed as a result of the influence of the external stimuli. The majority of researchers reject the opinion, stating that aggressive behaviour is either a deviation, an exceptional attitude, which can be manifested by an individual which has gone astray, or a reaction to any provocation, to a particular stimulus. If it is possible to determine, neutralise or possibly weaken the factor which causes violence, it will be possible to eliminate the phenomenon from the interpersonal relations. Nevertheless, it is impossible for science to predict when a given individual applies violence, or why a given group is organized to fight with the other, and the roots of war lie behind such phenomena. Regardless of the fact how large the share of an individual in war is, it still remains as an area of a group activity ${ }^{32}$.

For the purpose of the search of the sources of war, David Livingston Smith ${ }^{33}$ dates back six million years to an event of the separation of the ancestral line of human from the line of the chimpanzee. He states that people fought in a similar manner to their monkey cousins ${ }^{34}$. This is indicated by the behaviour of the chimpanzees, where groups of males controlled a given territory and arranged escapades within the other territory and attacked the encountered individuals of a different community. The prehistoric times of man indicate that his past was bloody and abundant in violence ${ }^{35}$. Due to the above, many researchers, who describe the phenomenon of war, think that the source of war in the violence which is present in the man and which formed him for thousands of years. It is the man who carries aggression by nature, maintains eagerness to arguments, conflicts, and fight ${ }^{36}$.

Professor Michał Huazrski compares two schools of thinking about the sources of wars on the level of an individual. The first is in favour of an optimistic vision of the human as a creature being good by nature, which changes under the influence of external factors. The other is featured by pessimistic insight into the human nature, according to the views of Titus Maccius Plautus and Hobbs (homo homini lupus est) ${ }^{37}$. Following the polemologists Gaston Bouthoul and René Carrera, group aggression is almost always the source of wars, it is caused by structures (demographic, economic, geographical, psychological [...] unstable as well as by frustrations and mistakes from which it results. Therefore, it is important to investigate how such irrational, chaotic

\footnotetext{
${ }^{32}$ J. Keegan, Historia wojen, Książka i Wiedza, Warszawa 1998, p. 89-95.

33 Professor David Livingston Smith works at University of New England where manages the Institute of Cognitive Science and Evolutionary Research and lectures on philosophy.

${ }^{34}$ D. L. Smith, Człowiek czlowiekowi wilkiem, the interview for M. Rutkiewicz, Polityka 2010, no. 19 , pp. $64-66$

${ }^{35}$ Ibidem.

${ }^{36}$ J. Gotowała, Konflikty zbrojne połowy XXI wieku, Bellona 2009, nr 2, p. 7.

${ }^{37}$ M. Huzarski, Przedmiot badan, zakres polemologii, Leceture, PhD studies, WZiD AON, Warszawa 2012.
} 
and unconscious aggressiveness can transform into rational and controlled hate. ${ }^{38}$ Thus, the reason of wars is aggression, instincts conceiving war, manifesting in advanced individual or group violence, darkening rational thinking. In organised societies its the economy (coincidence) which pushes into group aggression, causing the reactivation of complexes which commence wars. Hasty reasoning, panic fear, obsession of incessantly threatening danger provoke to specify an enemy responsible for what causes fear or a feeling of guilt in people. ${ }^{39}$

The sources of war have to be investigated on the level of a country as well. The views of Hippias of Abdera, the representative of the school of sophists, who saw the sources of war in the very existence of a country, are typical in this context . Plato saw the sources of war in natural hostility of tribes and overpopulation as well. Thomas Malthus noticed the sources of war in contradiction between the excessive population growth and limited possibilities of ensuring a suitable standard of living for a growing number of society.

It is also necessary to see the reasons of wars on the level of the international system. Countries follow mainly their reason of State, acting often against the norms of international law. They make decisions about war when they are certain that this will ensure that they achieve the planned political aims. In the reference books it is possible to notice the multitude of divisions of the causes of wars. The most frequently factors include territorial, political, economic, ideological, cultural, and ecological. ${ }^{40}$ The major reason for wars, both now and in the past, is a fight of countries for a territory. It relates to separatist or independence aspirations as well as arguments between countries for a border territory or a sphere of influence.

\section{CONCLUSIONS}

The discussion on war and peace is still current. After political guarantees that the Cold War had ended, after the breakdown of the Eastern Bloc, new threats occurred at the end of the $20^{\text {th }}$ century and the first decade of the $21^{\text {st }}$ century. Although they do not relate to a global disaster, peace is still threatened, though, and local wars are still endlessly conducted. The following more important problems wait for scientific consideration: international terrorism, nationalism, religious fundamentalism, also ethnic hostility are still sources of wars. Discussions on wars should not be limited to their evidence and description, to presentation of their negative effects, in present, historic as well as evolutionary terms. Due to the fact that wars occurred in the entire societies, they should be managed by some qualities which should be discovered in order to determine their basis as a result. The research on the etiology of war should be incessantly performed. Although the outbreak of a great war is currently improbable, in the future, though, it cannot be excluded.

${ }^{38} \mathrm{G}$. Bouthoul, R. Et Carrére, Le défi de la guerre, Paris 1976, s. 172; S. Topolewski, Etiologia wojen na przyktadzie wybranych poglądów $w$ literaturze europejskiej, [in:] M. Huzarski, A. Czupryński (red.), Wojna i pokój ..., op. cit., p. 180.

${ }^{39} \mathrm{~S}$. Topolewski, Etiologia wojen na przykładzie wybranych pogladów w literaturze europejskiej, [w:] M. Huzarski, A. Czupryński (ed.), Wojna i pokój ..., op. cit., p.181.

${ }^{40}$ Ł. Smalec, Dwie wojny ..., op. cit., pp. 22-25. 


\section{REFERENCES}

[1] Balcerowicz B., O pokoju. O wojnie, Wydawnictwo Rambler, Warszawa 2013.

[2] Borgosz J., Drogi i bezdroża filozofii pokoju (od Homera do Jana Pawta II), Warszawa 1989.

[3] Castells M., Społeczeństwo sieci, Warszawa 2008.

[4] Chmielarz, Wojna a państwo. Wczoraj i dziś, Wydawnictwo Naukowe Scholar, Warszawa 2010.

[5] Ciborowski L., Polemologia - stan obecny i perspektywy [w:] Huzarski M., Szulc B. (red.) Metodologiczna tożsamość polemologii, AON, Warszawa 2010.

[6] Czupryński A., Sztuka wojenna i polemologia $w$ aspekcie wspólnego obiektu poznania naukowego, [w:] Czupryński A., Polak A. (red.), Od sztuki wojennej do polemologii. Studia ofiarowane profesorowi Michałowi Huzarskiemu w siedemdziesiątą rocznicę urodzin, AON, Warszawa 2012.

[7] Drabik K., Polemologia dla pokoju, cz. I, Zeszyty Naukowe AON nr 3 (76), AON, Warszawa 2009.

[8] Fryc M., Wojna. Wspótczesne oblicze, Toruń 2009.

[9] Fukuyama F., Koniec historii, Zysk i S-ka, Poznań 1996.

[10] Gałganek A., Polemologia - badania nad wojna $i$ pokojem, Sprawy Międzynarodowe nr 6, Warszawa 1986.

[11] Gotowała J., Konflikty zbrojne połowy XXI wieku, Bellona 2009, nr 2.

[12]Huzarski M., Wojna $i$ pokój przedmiotem badań polemologicznoirenologicznych. Działalność naukowo dydaktyczna Zakładu Polemologii, [w:] Huzarski M., Czupryński A. (red.), Wojna i pokój przedmiotem badań polemologiczne-irenologicznych, AON, Warszawa 2012.

[13] Jacobsen H. A., Imperatyw pokoju. Polityka i wojna w XX wieku, Poznań 2000.

[14] Kagan R., Powrót historii i koniec marzeń, Dom Wydawniczy REBIS, Poznań 2009.

[15] Keegan J., Historia wojen, Książka i Wiedza, Warszawa 1998.

[16] Kęsoń T., Pojęcie konfliktu $i$ wojny w literaturze. Podejście polemologiczne $w$ badaniach konfliktów zbrojnych, Warszawa 2008.

[17] Kopaliński W., Stownik wyrazów obcych i zwrotów obcojęzycznych, PW „Wiedza Powszechna”, Warszawa 1989.

[18] Stownik języka polskiego, t. 1, PWN, Warszawa 1978.

[19] Stownik języka polskiego, t. 2, PWN, Warszawa 1979.

[20] Smalec Ł., Dwie wojny z Irakiem. Źródta, przyczyny, preteksty, przygotowanie, skutki, Warszawa 2012.

[21] Smith D. L., Człowiek człowiekowi wilkiem, wywiad udzielony M. Rutkiewiczowi, Polityka 2010, nr 19.

[22] Sun Tzu, Sztuka wojny, Wydawnictwo HELION, Gliwice 2008.

[23] Świniarski J., Myśl filozoficzna w polemologii, [w:] Huzarski M., Szulc B. (red.), Metodologiczna tożsamość polemologii, AON, Warszawa 2010.

[24] Toynbee A., Wojna i cywilizacja, Warszawa 1963.

[25] Topolewski S., Etiologia wojen na przykładzie wybranych pogladów $w$ literaturze europejskiej, [w:] Huzarski M., Czupryński A. (red.), Wojna i pokój przedmiotem badań polemologiczne-irenologicznych, AON, Warszawa 2012. 


\section{POKÓJ, WOJNA I KONFLIKT ZBROJNY OBIEKTEM BADAŃ}

\section{POLEMOLOGII}

Wojna, podobnie jak społeczeństwo, a wraz z nim państwo, zmienia się systematycznie. Podejście polemologiczne do badania wojny ma charakter negatywny i służy jej eliminacji z całokształtu życia społecznego. Trzeba zaznaczyć, że wojnę zazwyczaj postrzegano jako środek do osiągnięcia pokoju, a nie cel sam w sobie. Odmienność podejścia polemologicznego polega na zmianie statusu wojny. Wojna nie jest praktycznym środkiem osiągania pokoju, ale jest przedmiotem poznania, zaś celem tego poznania jest ostateczna eliminacja wojny z teorii i praktyki stosunków między ludzkich. Wojna nie jest zatem narzędziem lecz przedmiotem dociekań badawczych. Polemologiczne badanie wojny w założeniu poznawczym dostarcza wiedzy dotyczące jej etiologii, anatomii i funkcji społecznych, w założeniu utylitarnym pozwala uzyskać wnioski, jak postępować by uniknąć wojny. Uzyskana w ten sposób wiedza wskazuje jak kreować rzeczywistość, ażeby wojna stała się kategorią historyczną. Rezultatem poznania naukowego jest wiedza o wojnie którą należy wykorzystać aby jej zapobiegać. Istotę podejścia polemologicznego do badań wojny należy postrzegać $\mathrm{w}$ aspekcie poznawczym i praktycznym. Element poznawczy polega w głównej mierze na wyjaśnianiu związków przyczynowo-skutkowych, formułowaniu i weryfikowaniu hipotez oraz twierdzeń. Wymiar praktyczny dotyczy zadań dydaktycznych i informacyjnych. Skierowany jest przede wszystkim w stronę oddziaływania na społeczeństwo i wpływania na decydentów.

Słowa kluczowe: pokój, polemologia, wojna, konflikt zbrojny.

DOI:10.7862/rz.2015.hss.7

Przesłano do redakcji: grudzień 2014

Przyjęto do druku: czerwiec 2015 